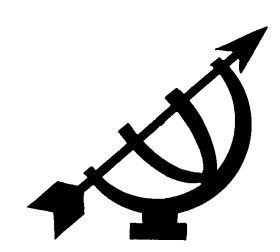

\title{
Ontwikkelingsamewerking vir Afrika, met besondere aandag aan 'n vennootskapsverhouding
}

\author{
B.J. van der Walt \\ Skool vir Filosofie \\ Potchefstroomkampus \\ Noordwes-Universiteit \\ POTCHEFSTROOM \\ E-pos: hannah@intekom.co.za
}

\section{Abstract \\ Development co-operation for Africa, with special reference to a partnership relation}

The problem to be investigated is whether development cooperation between especially the rich Northern part of the world and the African continent (including South Africa) is necessary or advisable. This question can be divided into the following three sub-questions: (1) Does Africa need development aid? (2) Will help from outside produce the needed results? (3) How can such cooperation be structured in the most efficient way? The three answers to these questions are: (1) Without outside help Africa will not be able to escape from its poverty trap. (2) In spite of the fact that development cooperation is at the moment experiencing a "mid-life crisis", both practical and Christian principial reasons do not allow its termination. (3) Many weak points in the existing forms of development cooperation may be overcome with the application of a genuine partnership relationship.

\section{Opsomming}

\section{Ontwikkelingsamewerking vir Afrika, met besondere aandag aan 'n vennootskapsverhouding}

Die probleem wat hier ondersoek word, is of ontwikkelingsamewerking tussen veral die ryk Noordelike wêreld en die kontinent Afrika (Suid-Afrika ingesluit) nodig en gewens is. Dié vraag kan in die volgende drie subvrae verdeel word: (1) Het Afrika ontwikkelingshulp nodig? (2) Sal sodanige hulp die no- 
dige resultate oplewer? (3) Hoe kan hierdie samewerking op 'n doeltreffende wyse geskied? Die drie antwoorde op hierdie vrae is soos volg: (1) Sonder hulp van buite kan Afrika nie uit die armoedefuik waarin dit gevange sit, loskom nie. (2) Hoewel ontwikkelingsamewerking tans 'n "middeljarige krisis" beleef, kan dit om sowel praktiese as prinsipieel-Christelike oorwegings nie gestaak word nie. (3) Heelwat swak punte in die bestaande vorms van ontwikkelingsamewerking sal oorkom kan word met die toepassing van 'n meer integrale vennootskapsverhouding.

\section{Inleiding}

Ter inleiding word eerstens verduidelik wat die vraagstuk is wat hier ondersoek word en tweedens die weg wat in die ondersoek gevolg sal word.

\subsection{Die vraagstuk: 'n verdeelde maar gedeelde wêreld}

Die mensheid lewe in 'n verdeelde wêreld (vgl. die belangrike werk van Goudzwaard \& De Lange (1995) en Van der Walt (1999) oor die oorontwikkelende Noorde en Weste en die onderontwikkelde Suide). Die wêreld is hoofsaaklik verdeel tussen baie arm en baie ryk mense, lande en streke. Daar bestaan nie net globaal 'n skreiende teëstelling tussen die ryk Noorde en die arm Suide nie, maar ook in dieselfde streek/gebied, byvoorbeeld Europa (vgl. Boersma, s.a.) en selfs in dieselfde land, byvoorbeeld Suid-Afrika.

'n Vraag wat telkens opduik, is of die arm mense self vir hulle armoede verantwoordelik is en indien wel, presies watter aandeel die ryk lande daarin gehad het of nog het. Hamelink en Visser (2002:136), twee Nederlandse skrywers, is van mening dat armoede in die suidelike deel van die wêreld nie alleen as gevolg van die optrede van die Noorde in die verlede ontstaan het nie, maar nog steeds deur die noordelike lande (bv. deur handelsbeperkings) in stand gehou word. Ook Goudzwaard en De Lange (1995), pleit in die geval van die Noorde vir 'n "ekonomie van genoeg". Presies die teenoorgestelde standpunt, wat al die skuld op die skouers van die arm lande pak, word egter ook gehoor (vgl. 5.4.1 later). Die skrywer is van mening dat sulke oor-en-weer beskuldigings nie baie vrugbaar is om die reële probleme van die skreiende armoede in Afrika op te los nie.

Behalwe 'n verdeelde wêreld, moet onthou word dat ons ook in 'n "gedeelde wêreld" lewe - arm en ryk deel één wêreld. God het hierdie wêreld geskep, dit aan die mens opgedra om daarvoor te sorg, asook na sy medemens om te sien. As gevolg van globali- 
sering word die wêreld al kleiner, sodat rykes nie langer armes kan ignoreer en omgekeerd nie. Samewerking word 'n voorwaarde vir oorlewing van jouself en van jou eie ryk land of streek. Vergelyk byvoorbeeld aardverwarming en die milieukrisis.

Ook vanuit 'n Bybelse perspektief is die groot kloof tussen arm en ryk onaanvaarbaar, veral indien die een se rykdom die ander se armoede impliseer (vgl. byvoorbeeld die profetiese boeke soos Amos en Miga). Dit is 'n bekende feit dat die meerderheid Christene vandag in die armer streke (Afrika, Asië en Latyns-Amerika) lewe en hulle getalle vinnig toeneem (vgl. byvoorbeeld Jenkins, 2002 en Jenkins, 2006). Nogtans bly die finansiële mag en kontrole in die hande van die steeds krimpende getal noordelike Christene. In hierdie verband merk Tshimika en Lind (2003:18) op: “... there are strong and stubbornly entrenched patterns in the relationships between churches in the South and North that contradict our biblical beliefs".

Met die begrippe verdeelde en gedeelde wêreld word die twee fokuspunte van hierdie artikel aangedui. Eerstens (as agtergrond en probleemstelling) word aangetoon hoe rykdom en armoede die wêreld verdeel. Tweedens (die moontlike oplossing) word aangetoon hoe ryk en arm kan deel om 'n beter gemeenskaplike (gedeelde) wêreld te skep.

\subsection{Die opset}

Die artikel verloop soos volg: Ter inleiding word enkele statistieke gegee waaruit die groot en groeiende kloof tussen arm en ryk oor die wêreld en in Afrika in die besonder sal blyk, asook enkele oorsake en moontlike oplossings vir hierdie ongewenste situasie. Daarna word besin oor dit wat armoede presies inhou. Vervolgens word kortliks aangedui hoe daar sowel in die Christelike as in die meer sekulêre denke geleidelik breër visies op armoedebestryding ontwikkel het. Dan word ondersoek waarom ontwikkelingshulp met ontwikkelingsamewerking vervang is, wat laasgenoemde inhou asook die probleme wat daaraan verbonde is. Hierna word die vennootskapsmodel (met die voor- en nadele daaraan verbonde) ondersoek as ' $n$ moontlikheid vir meer bemagtigende samewerking. Ten slotte word aangetoon hoe 'n vennootskapsverhouding aansluit by die huidige klem op "civil society" en ook verder uitgebou kan word in die lig van 'n Christelike samelewingsfilosofie. 


\section{Groot armoede in veral Afrika, moontlike oorsake en oplossings}

\subsection{Amoede wêreldwyd}

Soos reeds gestel, is armoede nie tot Afrika beperk nie. Om 'n idee van die omvang daarvan te kry, lees Gasper (2004:2-12) se inleiding tot ontwikkelingsetiek. Hierdie tien bladsye bevat die mees skokkende gegewens oor ongelooflike weelde aan die een kant en skreiende armoede en ontsettende lyding as gevolg daarvan oor die hele wêreld aan die ander kant. As noodsaaklike agtergrond word kortliks eers na die huidige ekonomiese toestand in die wêreld as 'n geheel gekyk en dan spesifiek na Afrika, asook die moontlike oorsake en oplossings vir die armoede van hierdie kontinent.

\subsubsection{Die globale situasie}

Sachs $(2005: 18)^{1}$ verdeel die huidige wêreldbevolking in die volgende vier kategorieë:

- Die uiterste armoediges wat met minder as \$1 per dag moet probeer oorleef. Hulle maak ongeveer een biljoen of een sesde van die totale mensdom uit.

- Die armes wat met moeite tog kan oorleef, omdat hulle in hulle basiese lewensbehoeftes kan voorsien. Hulle maak ongeveer 1,5 biljoen van die totaal uit.

- Die middelinkomstegroep van ongeveer 2,5 biljoen.

- Die hoë inkomstegroep wat op ongeveer een biljoen neerkom.

Diegene wat in uiterste armoede leef is volgens Van Til (2007) nie $17 \%$ nie, maar $40 \%$. Hulle het nie genoeg om in hulle basiese bestaansbehoeftes te voorsien nie en hulle is dus meestal honger en siek, beskik nie oor skoon drinkwater, sanitasie, of ordentlike behuising nie en kan ook nie onderwys vir hulle kinders bekostig nie. Volgens Sachs kan hulle ook nie self sonder hulp van buite uit die armoedefuik waarin hulle gevange is, ontsnap nie. Na raming sterf

1 Hierdie werk sal telkens in hierdie ondersoek aangehaal word, nie alleen omdat dit een van die mees resente werke op die gebied van ontwikkelingsekonomie is nie, maar veral as gevolg van die gesaghebbendheid daarvan. Die outeur word as een van die wêreld se 100 mees invloedryke mense bestempel. As adviseur vir sukkelende ekonomieë wêreldwyd beskik hy ook oor waardevolle praktiese ervaring. 
agt mijoen van hierdie groep mense jaarliks van honger/ondervoeding.

Die situasie raak nog meer kritiek indien die volgende in gedagte gehou word: na 'n aanvanklike daling in armoede, het dit sedert ongeveer 1996 weer begin styg tot 1,2 miljard (vgl. Buijs, 2001:12 en Verbeek, 2005:26). Die kloof tussen arm en ryk in die wêreld word ook al groter. Buijs $(2001: 12,25)$ toon aan dat die 600 miljoen allerarmste mense sáám slegs een agtste per jaar verdien van die inkomste van die 200 rykste mense in die wêreld. In die derde plek toon Sachs (2005:82) aan dat die ontwikkelingshulp aan die armstes vanaf ongeveer 1980 verminder het.

\subsubsection{Die situasie in Afrika}

Veral Afrika suid van die Sahara is die heel armste deel van die wêreld (vgl. Van der Walt, 2006a:18 e.v.). Sachs (2005:21) plaas drie jaar gelede $50 \%$ van die bevolking van sub-Sahara Afrika in die kategorie van die "extreme poor". (Indien die huidige statistiek verlang word, kan dit maklik op die VN se webtuiste verkry word.)

Hoewel uiterste armoede in Suid- en Oos-Asië vanaf 1980 begin daal het, het dit in Afrika toegeneem. Volgens Sachs (2005:189) is Afrika vandag armer as met onafhanklikwording 50-60 jaar gelede, of toe groot ontwikkelingsorganisasies, soos die Wêreldbank en die Internasionale Monetêre Fonds vanaf die sestigerjare op die toneel verskyn het. Ook Verbeek (2005:26) moet met hartseer konstateer dat die ekonomiese ontwikkeling in Asië en Latyns-Amerika Afrika verbygegaan het.

Skokkende statistieke oor Afrika is die volgende:

- 10 000-15 000 mense sterf daagliks aan siektes soos malaria, tuberkulose, VIGS (Sachs, 2005:208).

- Tussen een tot drie miljoen kinders sterf jaarliks in Afrika (Sachs, 2005:7).

- In 2000 was die gemiddelde lewensverwagting van mense in Afrika slegs 47 jaar, dit wil sê 31 jaar minder as die 78 jaar vir ontwikkelde lande. In sommige gevalle is dit slegs 20 jaar as gevolg van die VIGS-pandemie (Sachs, 2005:194).

Wat sou die redes vir sulke armoede kon wees? 


\subsection{Moontike oorsake vir Afrika se onderontwikkeling}

Sachs (2005) kritiseer tereg eers die steeds gangbare opvatting dat die fout alleen by Afrikane en veral die Afrikaregerings lê en Afrika dus alleen self die skuld moet dra. Volgens Sachs is dit 'n eng prentjie, soos reeds bewys deur die mislukking van die strukturele aanpassingsprogramme wat gelei het tot nog groter armoede in Afrika.

Wat is dan die werklike oorsake? Sachs se antwoord belig die volgende aspekte:

- Fisiese geografie: Hoewel Sachs nie 'n "geografiese determinis" is nie, speel die geografie van 'n land/gebied ' $n$ belangrike rol. Natuurlike hulpbronne, vrugbare grond, genoeg reën, bevaarbare riviere, genoeg hawens, ensovoorts maak vooruitgang beslis makliker as in die geval van byvoorbeeld 'n afgeslote berglandskap.

- Die fiskale fuik: Daar ontbreek by sommige regerings kapitaal om die nodige infrastruktuur wat vir ekonomiese groei noodsaaklik is, te voorsien. Die redes hiervoor kan, behalwe vir arm burgers en 'n groot skuldelas, ook die korrupsie van regerings wees.

- Geopolitiese oorsake: Die belangrike rol wat internasionale handel in ontwikkeling kan speel en die nadelige gevolge van onnodige handelsintervensies en sanksies asook oorloë en die vlugtelingsprobleem word hier beklemtoon.

- Demografiese faktore: In arm lande is die geboortesyfer as gevolg van 'n gebrek aan gesondheidsorg en die aantal kindersterftes baie hoër as in ryk lande. Dit het nadelige gevolge vir ekonomiese ontwikkeling, omdat dit onmoontlik is om aan die kinders voedsel, gesondheidsorg en onderwys te verskaf.

- Gebrek aan innovasie: Hieronder verstaan Sachs die gebrek aan wetenskaplike kennis en tegnologiese middele van die arm lande. Omgekeerd was die ontwikkeling van wetenskap en tegnoogie volgens hom dié geheim van ekonomiese groei in die Weste.

\subsection{Die moontike oplossings}

Volgens die doelwitte van die VN se Millennium Ontwikkelingsplan kan vir elke land (vgl. Sachs, 2005:82) 'n differensiaaldiagnose gemaak word om te bepaal wat die belangrikste struikelblokke en oplossings op die pad na ontwikkeling is. 


\subsubsection{Wat Afrika nodig het}

Volgens Sachs (2005:244) het Afrika die volgende soort "kapitaal" nodig:

- Menslike kapitaal soos voedsel, gesondheid en onderwys (om die nodige vaardighede te bekom);

- besigheidskapitaal soos masjiene, vervoer en industrieë;

- infrastrukturele kapitaal soos paaie, elektrisiteit, water, sanitasie, lug- en seehawens en telekommunikasiegeriewe;

- natuurlike kapitaal soos genoeg en vrugbare landbougrond en gesonde ekosisteme;

- openbare kapitaal soos effektiewe regeringsdienste, regstelsels, polisiëring; en

- kenniskapitaal waaronder veral wetenskaplike en tegnologiese kennis bedoel word.

Op oortuigende wyse toon Sachs (2005:255) ook aan dat daar nie net een "magic bullet" vir ontwikkeling bestaan nie. Al hierdie kapitale moet tegelyk aanwesig wees om 'n goeie ekonomie te verseker. Hy toon byvoorbeeld aan (Sachs, 2005:240) dat daar nie eenvoudig gesê kan word dat siekte óf die resultaat óf die oorsaak van onderontwikkeling is nie. Die oorsaaklikheid werk in albei rigtings: swak gesondheid veroorsaak armoede en omgekeerd dra armoede by tot swak gesondheid.

'n Tweede belangrike voorwaarde is dat die armste van die armes in Afrika alleen met hulp van buite uit die armoedefuik bevry kan word. Hulle kan nie hulself bevry nie, omdat hulle eenvoudig nie oor die nodige kapitaal beskik om hulle voete (as individue en regerings) op die heel eerste trappie van die "ontwikkelingsleer" te plaas nie. Die mense van Afrika bevind hulself "in the worst poverty trap in the world" (Sachs, 2005:73, 208).

Uiterste armoede laat mense nie toe om te spaar nie en hulle regerings om die nodige belasting te hef nie, omdat hulle hul totale, karige inkomste moet gebruik om daagliks te kan oorleef. Die dimensies van sulke uiterste armoede is onder andere die volgende: kroniese honger en ondervoeding, kwesbaarheid vir siektes, uitsluiting uit (selfs primêre) onderwys, die gebrek aan basiese geriewe soos skoon drinkwater en sanitasie; 'n gebrek aan die noodsaaklikste infrastruktuur, soos paaie, vervoer, elektrisiteit, landbou-imple- 
mente, kommunikasiemiddele, ensovoorts; agteruitgang van die omgewing as gevolg van gronderosie en ontbossing.

Sonder ontwikkelingshulp/-samewerking kan Afrika se armoedeprobleem dus nie opgelos word nie. Die bedoeling is nie om Afrikane te verryk nie, maar slegs om hulle te help om in meer as net hulle basiese lewensbehoeftes te voorsien, sodat hulle met die reserwekapitaal geleidelik die ontwikkelingsleer kan begin klim.

\subsubsection{Is dit haalbaar?}

Sachs (2005:288 e.v.) noem behalwe historiese voorbeelde ter inspirasie (soos byvoorbeeld die Marshall Plan na die Tweede Wêreldoorlog), ook die volgende redes waarom so 'n grootse poging vir die beëindiging van armoede in Afrika vandag wel moontlik is:

- Terwyl die helfte van die wêreldbevolking 60 jaar gelede uiters arm was, is dit vandag net die geval met ongeveer een sesde daarvan.

- Die wêreld (veral die Weste) het intussen ook baie ryk geword en kan dié hulp dus sonder eie skade bekostig.

- Die wetenskaplike en tegnologiese vermoë bestaan wel om dit te kan doen.

- Daar is vandag baie lande (soos Indië, China, Meksiko) wat hulleself kan help, omdat hulle reeds ' $n$ voet op die ontwikkelingsleer het. Dit is hoofsaaklik Afrikalande wat oorbly.

- So 'n ontwikkelingsprogram wil dus nie alle armoede bestry of 'n gelykskakeling tussen arm en ryk nastreef nie, maar alleen die allerarmstes help om hulle uiteindelik self te kan help.

- Die bedoeling is ook nie om kontant na die arm lande oor te plaas nie. Dit gaan oor beleggings in die infrastruktuur en menslike kapitaal (kyk hierbo).

- Indien die ryk lande, veral die VSA, bereid is om daadwerklik slegs $0,05 \%$ van hulle bruto nasionale inkomste te gee in plaas van die $0,07 \%$ wat reeds 35 jaar gelede beloof is, kan uiterste armoede in Afrika teen 2015 reeds van $40 \%$ tot $20 \%$ daal.

... it is painfully clear that the funds are ample and even residing in the accounts of a few hundred of the U.S.'s superrich, not to mention the four million or so American households with net worth in excess of $\$ 1$ million, or the eight million or so households worldwide, or the one billion people in total who live 
in the high-income countries with a combined income of some $\$ 30$ trillion (Sachs, 2005:364).

Daar is dus genoeg vir almal in die wêreld se behoeftes. Wat ontbreek, is die politieke en morele wil om iets daaraan te doen.

\subsubsection{Te eensydig ekonomies?}

Daar is nie sonder redes lank stilgestaan by die belangrike bevindings van Sachs nie. Aan die een kant het dit positief gehelp om 'n goeie insig te verkry in die huidige situasie van Afrika se armoede, die moontlike oorsake en oplossing daarvan en veral die noodsaak van ontwikkelingsamewerking uit die buiteland.

Aan die ander kant kan ook op negatiewe wyse daaruit geleer word. Sachs se boek is 'n tipiese voorbeeld van die Westerse, modernistiese idee van die "maakbaarheid" van die samelewing deur middel van wetenskap, tegniek en ekonomie (vgl. Jongeneel, 2006:15 en ook Schuurman, 2005). Daar word nie besef dat ontwikkelingsekonomie en praktiese ontwikkelingswerk deur mense en vir of met mense verrig word nie. Sachs $(2005: 57,60,317)$ is van mening dat kultureel-sosiale faktore nie eintlik relevant is nie. So 'n reduksionistiese, ekonomistiese idee van ontwikkeling hang saam met ' $n$ baie eng visie op wat armoede is. Dit bring ons by die tweede hoofpunt van die artikel:

\section{Voortgaande besinning oor amoede}

Hoe 'n mens armoede probeer bestry, hang af van hoe 'n mens armoede beskou en wat dit presies behels. Indien 'n mens (soos Sachs hierbo en baie Afrikaleiers) armoede reduseer tot 'n materiële toestand van gebrek aan dinge soos geld, kos, water, elektrisiteit, behuising, ensovoorts, sal ontwikkeling as antwoord daarop ook tot materiële oplossings beperk wees (vgl. Myers, 2001:4 asook Goudzwaard \& De Lange, 1995 se veel breër benadering).

\subsection{Wat ammoede werklik inhou}

Navorsing en praktiese ervaring die afgelope paar dekades het egter aangetoon dat so 'n eng visie op armoede nie duidelik kan maak wat armoede werklik behels nie en dus ook nie die probleem werklik kan bekamp nie. Die begrip armoede het geleidelik 'n breër, meer omvattende betekenis gekry, naamlik vanaf 'n blote gebrek aan middele, na 'n tekort aan kennis, na beperkings op vryheid, kiesmoontlikheid, mag, sosiale invloed en dies meer (vgl. Myers, 2001: 12). 
Die bekende ekonoom en Nobelpryswenner, Sen (1999), beklemtoon dat die kwaliteit van die menslike lewe nie in terme van materiële dinge gemeet kan word nie, maar in terme van vryheid of kiesmoontlikheid. Ekonomiese ontwikkeling wat dit nie bevorder nie, het misluk.

Bruwer (1994) verander dus die bekende gesegde "beggars can't be choosers" na "beggars can be choosers" en sê:

Development without the element of choice is highly questionable. In Christian benevolence there is no place for beggarism, dependency and passive acceptance, but only for a life through choice and the acceptance of responsibility: an act of will. The basic appeal of the Gospel is an appeal to the will: stand up and walk! (Bruwer, 1994:21.)

Dié kenmerk van armoede is 'n diepgewortelde gevoel van magteloosheid om iets aan jou eie situasie te kan doen. Bruwer verduidelik:

The effects of poverty penetrate right into the human mind and soul. The feeling of total hopelessness leaves the poor in a state of utter helplessness and lack of initiative and despondency. To be motivated to get out of poverty is already one step ahead. (Bruwer, 1994:18; vgl. ook Perkins, 1993.)

Omdat permanente magteloosheid tot 'n swak selfbeeld lei, affekteer dit nie net uiterlike, materiële omstandighede nie, maar tas dit mense se wese, hul identiteit aan. Aan die ander kant word die rykes, wat geneig is om as verlossers of gode vir die armes op te tree, se identiteit ook aangetas (vgl. Myers, 2001:xviii).

Volgens Myers (2001:13) is die oorsaak van armoede dus meestal geestelik, terwyl die aard meestal relasioneel is. Dit affekteer al die verhoudings van die mens: die verhouding tot homself, die medemens, die natuur en die transendente (God). Werklike ontwikkeling kan volgens Myers en Bruwer (1994:18) dus alleen vanuit die menslike gees begin, sodat daardie verhoudings ook kan verander. In ooreenstemming hiermee pleit Van der Walt (1999; 2001 en 2003) vanuit 'n Christelike mensvisie vir ontwikkeling as 'n multidimensionele proses waarin die sosiaal-kulturele ten volle erken word, in plaas van ontwikkeling as 'n eng ekonomies-tegniese bedryf. 


\subsection{Bamhartigheid alleen is nie voldoende nie}

Omdat armoede ook die gevolg is van sosiale onmag en onreg, kan blote noodhulp of liefdadigheid alleen dit nie oplos nie, maar dit kan eerder die probleem vererger.

\subsubsection{Bamhartigheid met omsigtigheid beoefen}

Die probleem met blote liefdadigheid is dat dit die gevoel van hopeloosheid en afhanklikheid by die armes net kan versterk (vgl. Perkins, 1993:21 e.v.). Hulle raak geneig om die oplossing vir hulle armoede net buite hulself te soek. Volgens Perkins (1993:24) kan die verkeerde manier van gee dus net so destruktief wees as die armoede wat dit wil verlig. Dit beteken nie dat liefdadigheid geen plek het nie, maar dit is slegs die begin- en nie die eindpunt van 'n oplossing nie.

Hulp moet dus met omsigtigheid gebied word, omdat dit arm mense se minderwaardigheidsgevoel kan versterk:

Receiving is a humbling matter. It implies neediness. It catagorizes one as being worse off than the giver. Therefore we should be careful how we give. Giving should affirm and not dehumanize. We give because God gave to us. We should be humbled by our opportunities to give ... Somehow we have to disconnect what and how we give from our need to feel good about ourselves. (Perkins, 1993:28.)

Perkins erken egter dat dit makliker is om op onpersoonlike wyse 'n aalmoes te gee as om betrokke te raak by die konkrete ontwikkeling van minderbevoorregte mense.

Bruwer (1994:9-11) waarsku verder dat armes hulp as indringing in hulle persoonlike lewe en 'n bedreiging van hulle menswaardigheid kan beskou. Die teken van ware armoede is stilswye. Om hulp te veto, is 'n stilswyende of apatiese manier van weerstand of protes teen die verkeerde soort hulp. Armes kan egter ook verder gaan en self alternatiewe oplossings vir hulle probleme soek. Ten einde nog harder en duideliker "nee" te sê, mag hulle selfs tot agressie oorgaan en die simbole en magstrukture van die rykes aanval. In die meeste sulke gevalle roep hulle om erkenning en respek vir hulle menswaardigheid. Die enigste weg om dié gaping (van die veto deur armes) te oorbrug, is deur ware medelyde en nie hulp op 'n afstand nie. 


\subsubsection{Bamhartigheid én geregtigheid}

Tot onlangs nog is ' $n$ vurige debat tussen evangeliese en ekumeniese Christene gevoer oor waarop die klem by hulpverlening aan armes gelê moet word: barmhartigheid of geregtigheid? (vgl. Verbeek, 2005:45 e.v.)

Hierdie debat was die resultaat van 'n dualisme tussen die geestelike en wêreldse. Dit is tyd om finaal daarvan afskeid te neem, omdat dit onbybels is. God is volgens die Skrif sowel die barmhartige Vader, wat Hom ontferm, as die onpartydige Regter wat in geregtigheid oor onreg oordeel.

We kunnen het met elkaar eens zijn dat de tegenstelling tussen persoonlijke en publieke gerechtigheid een geforceerde tegenstelling was. De Bijbel spreekt over zowel het een als het ander, niet in afzondering, maar juist in een sterke samenhang: ze volgen uit elkaar. (Verbeek, 2005:63.)

Elders stel Verbeek (2005:78) dit soos volg: Die persoonlike verlossing van mense behoort tot uiting te kom in 'n korresponderende lewenstyl en maatskaplike betrokkenheid. Dié twee fasette van die Christelike lewe is onlosmaaklik met mekaar verbonde (vgl. Matt. 7:16-18, 21). Vir die individuele Christen kan persoonlike regverdiging in Christus 'n motiverende krag wees om maatskaplike geregtigheid na te streef. Omgekeerd wys die konkrete konfrontasie met onreg in die samelewing elke keer weer die vinger na onsself ons onmag, onvermoë en onbekeerdheid.

Die implikasie van so 'n holistiese visie vir ontwikkelingshulp lê voor die hand: hulporganisasies moet sowel barmhartigheid (bv. noodlenigingswerk) as geregtigheid (bv. betrokkenheid by situasies van onderdrukking) nastreef.

\subsection{Verskillende kategorieë van ames}

In die lig van so 'n omvattende visie op armoede kan Sachs se blote ekonomiese indeling (tussen uiters armoediges en die groep wat met moeite tog nog oorleef - vgl. 2.2.1 hierbo) verder verfyn word. 'n Indeling in kategorieë kan 'n mens help om 'n beter greep op die komplekse verskynsel van armoede te verkry en dit ook beter te help bestry. Hamelink en Visser (2002:31 e.v.) stel die volgende drie kategorieë voor:

- Die ekonomies armes: wat verder (soos Sachs doen) onderverdeel kan word. Aan hulle moet barmhartigheid bewys word. 
- Die magteloses: Soos hierbo reeds geblyk het, is daar 'n noue verband tussen ekonomiese of materiële armoede en magteloosheid - die een lei tot die ander en omgekeerd. Magteloosheid is egter ook die resultaat van baie ander faktore, soos ongelyke sosiale verhoudings, politieke onderdrukking, onveiligheid, gebrek aan onderwys, sekere godsdienstig-lewensbeskoulike oortuigings en so meer. In hierdie geval moet daar veral na groter geregtigheid gestreef word.

- Die geestelike armes: is die manier waarop die twee vorige dimensies van armoede beskou word. (Vgl. die houding van magteloosheid en hopeloosheid hierbo beskrywe.) By rykes word daar 'n ander vorm van geestelike armoede, naamlik materialisme, aangetref.

Vir effektiewe armoedebestryding is dit noodsaaklik dat al hierdie verskillende gestaltes van armoede sover moontlik gelyktydig hanteer word. Dit bring ons by 'n volgende belangrike punt:

\section{4. 'n Breër, holistiese visie op armoedebestyding}

In ooreenstemming met ' $n$ minder reduksionistiese en meer omvattende visie op armoede het sedertdien ook 'n breër visie op ontwikkeling (in die geval van die sekulêre denke) en hulpverlening (in die geval van die Christelike nadenke) ontstaan. lets meer oor elkeen van hulle is belangrik.

\subsection{Volhoubare ontwikkeling}

In plaas van die ideaal van onbeperkte ekonomiese groei, het volhoubare ontwikkeling vandag die sleutelwoord geword.

Die Wikipedia:3 (2007) onder "Sustainable development" sê egter tereg:

Sustainable development is a notoriously ambiguous concept, as a wide array of views have fallen under its umbrella ... Thus the concept remains weakly defined and contains a large amount of debate as to its precise definition.

Dit is belangrik om te besef dat die begrip in die Weste ontstaan het en in die eerste plek op hierdie gebied van toepassing is. Goudzwaard en De Lange (1995:117) merk tereg op dat die kombinasie van "volhoubaar" en "ontwikkeling" impliseer dat iets verkeerd geloop het in die ideaal van ontwikkeling. 
Verdere kritiek is dat "volhoubare ontwikkeling" 'n oksimoron is, omdat dit twee teenstrydige begrippe met mekaar verbind. Hoe kan voortgesette ontwikkeling (= groei en verdere uitputting van bronne) volhoubaar wees indien die bronne beperk is? Sommige omgewingsbewustes beskou dié term dus gewoon as 'n slim slagspreuk van die kapitalistiese sakewêreld om hulle (mense wat oor die omgewing bekommerd is) te paai (vgl. Wikipedia, 2007:4).

Rist, wat die gedagte van volhoubare ontwikkeling in detail bespreek, stem saam: die selfstandige naamwoord ("ontwikkeling") is die bepalende en nie die byvoeglike naamwoord ("volhoubare") nie. Hy voeg daaraan toe:

... sustainable development looks like a cover-up operation: it allays the fears aroused by the effects of economic growth, so that any radical change can be averted. Even if the bait is alluring, there should be no illusion about what is going on. The thing that is meant to be sustained is 'development', not the tolerance capacity of the ecosystem or of human societies. (Rist, 1999:194.)

Volgens Rist kan die dubbelsinnigheid van die begrip nie tot veel lei nie. Die arm Suide staan op die reg om ook, soos die Noorde, te kan ontwikkel; en die Noorde bly oorgegee aan ekonomiese groei - in albei gevalle tot nadeel van die natuurlike en sosiale omgewing.

Aangesien die artikel van Du Pisani (2007:193-218) breedvoerig op die geskiedenis van en probleme rondom die begrip "volhoubare ontwikkeling" ingaan, word hier alleen nog vermeld dat hierdie begrip geleidelik verbreed is. Sedert 1990 sluit dit byvoorbeeld ook volhoubare sosiale ontwikkeling in. Tans is die "vier pilare" van volhoubare ontwikkeling (vgl. Wikipedia, 2007:2) behalwe die ekonomiese en die omgewing ook die sosiale en die politieke terreine.

\subsection{Holistiese ontwikkeling}

Soos wat die begrip "ontwikkeling" binne die sekulêre denke geleidelik verbreed het, het ook Christendenkers se visie op die nood van hulle medemens meer holisties geword (vgl. 3.2.2 en 3.3 hierbo). Dit geld sowel die sogenaamde evangeliese as die ekumeniese groeperings. (Van Til, 2007 behandel ook die Rooms-Katolieke denke op hierdie gebied.) 


\subsubsection{Die kentering by evangeliese Christene}

Tot ongeveer 1970 het hierdie groep nog gebuk gegaan onder die onbybelse dualisme tussen die materiële en die geestelike (vgl. Myers, 2001:5 e.v.). Daar moes dus in 'n valse dilemma gekies word tussen óf evangelieverkondiging óf sosiale betrokkenheid. $\mathrm{Na}$ Lausanne (1974) en Wheaton (1983) verskuif die klem na én evangelisasie én ontwikkeling (vgl. Samuel \& Sugden, 1987:245-265 vir die Wheaton statement: "Transformation: the church in response to human need").

Natuurlik is met die én-én visie die dualisme nie heeltemal opgehef nie (op hierdie wyse bly dit nog twee afsonderlike sake wat op een of ander wyse geïntegreer moet word). Nogtans is die deur vir Christelike betrokkenheid by die verandering van sosiale strukture oopgemaak. Armes hoef nie langer net individueel by wyse van evangeliverkondiging en barmhartigheid gehelp te word nie. Ook strukturele armoedebestryding (die tweede kategorie van die magteloses onder 3.3.2 hierbo) is belangrik. Die meeste Christene binne die evangeliese groep (vgl. ook vroeëre werke soos Hengel, 1974; Sider, 1977; Schrotenboer, 1978; Dickinson, 1983 en meer resente werke soos Taylor, 2000; Tshimika \& Lind, 2003; Van der Walt, 2006a en Van Til, 2007) erken vandag dat die materiële, sosiale en geestelike node (vgl. weer die drie kategorieë onder 3.3) verweef is en tegelyk in 'n holistiese benadering hanteer behoort te word. Ongelukkig gebeur dit nog nie altyd in die praktyk nie.

\subsubsection{Die stand by die ekumeniese groep}

Uit die werk van Swart (2006) blyk dat ook by hierdie groep ten minste drie "generasies" van nadenke onderskei kan word: eers noodhulp, toe gemeenskapsontwikkeling en later volhoubare sisteme, terwyl dit vandag na 'n nog breër globale benadering beweeg om ook internasionale verhoudings te probeer verander.

\subsection{Volhoubare of holitiese ontwikkeling?}

Uit die voorafgaande blyk dat sowel die sekulêre as die Christelike denke vandag saamstem dat ontwikkeling, indien dit geslaagd wil wees, nie net op een faset (bv. die ekonomies-materiële) mag konsentreer nie. Omdat onwikkeling met mense te make het wat multidimensionele wesens is, mag dit nie anders as omvattend van aard wees nie.

Soos hierbo (by 4.1) geblyk het, gaan die begrip "volhoubare" of "duursame" (in Nederlands) ontwikkeling nog steeds mank aan 
onduidelikheid en word dit met agterdog deur die suidelike, arm lande bejeën. Daarom mag dit terminologies verstandiger wees om eerder van "holistiese" ontwikkeling te praat.

Hiermee is die eerste fokuspunt van die artikel, naamlik die probleem van 'n verdeelde wêreld tussen ryk en arm, afgehandel. Daar kan dus oorgegaan word na die twee hooffokus: die oplossing waaraan ryk en arm kan saamwerk ter bereiking van 'n beter gedeelde wêreld.

\section{Ontwikkelingshulp/-samewerking as oplossing vir die amoede van Afrika}

Oor die wyse hoe 'n verdeelde wêreld verander kan word na 'n meer gedeelde wêreld, het daar gedurende die afgelope ongeveer vyftig jaar ook belangrike denkverskuiwings plaasgevind.

\subsection{Ontwikkelingshulp}

Die eerste poging in hierdie verband was ontwikkelingshulp. Dit het dikwels uit direkte geldelike steun of lenings aan regerings in Derdewêreldlande bestaan. As gevolg van die feit dat sulke regerings die ontwikkelingsproses wou domineer in plaas daarvan om slegs as katalisators of fasiliteerders op te tree en dikwels ook korrup was, het ontwikkelingshulp dus groot teleurstellings opgelewer (Zeylstra toon reeds in 1975 sodanige probleme aan).

\subsection{Ontwikkelingsamewerking}

Nie bloot genoemde probleme en die eensydig-paternalistiese konnotasie van "hulp" nie, maar veral verdere ervaring het duidelik laat blyk dat ontwikkeling nie van die kant van die ryk skenkers (van "bo" af) alleen bewerk kan word nie. Die mense vir wie dit bedoel is, moet ook 'n rol daarin hê. Plaaslike deelname is van kardinale belang. "By any means, local participation is a critical success factor for transformational development" (Myers, 2001:147).

Myers beklemtoon verder dat hierdie samewerking alles moet insluit - navorsing, beplanning, implementering en evaluering. Almal moet daarby betrek word: diegene wat dit befonds, wie dit uitvoer en op wie dit gerig is. Verder moet almal as egte, gelyke vennote erken word. Met ander woorde: integrale en onbeperkte samewerking.

Verbeek (2005:232) omskryf ontwikkelingsamewerking soos volg: 
Ontwikkelingssamewerking is het brengen van verbetering in de materiële en geestelijke situatie van de armen en verdrukten in de samenleving met betrekking tot (de toegang tot) basisbehoeften en de onrechtvaardige structuren op lokaal, nationaal en internationaal niveau, onder de voorwaarde dat er sprake is van partnership, duurzaamheid, wederkerigheid en ownership.

In die lig van die feit dat arm mense gekenmerk word deur magteloosheid (vgl. 3.1 en 3.3 hierbo), moet sodanige samewerking ook uitdruklik op hulle bemagtiging gerig wees. Wanneer mense self nie verander nie, sal baie min op die lang termyn aan hulle omstandighede verander. Bemagtigende deelname is volgens Myers (2001:149) en baie ander kenners die kern van werklike ontwikkelingswerk.

\subsection{Amoedebestryding?}

Hamelink en Visser $(2002: 13,14)$ verkies egter nog steeds eerder die begrip "armoedebestryding" in plaas van "samewerkingsontwikkeling". Hulle motiveer dit soos volg: Ontwikkeling is 'n onduidelike begrip en kan die indruk skep dat arm mense ook op ander terreine as die ekonomiese "onderontwikkeld" is. Dit is verder 'n vraag of daar werklik van samewerking sprake kan wees indien ontwikkelingsorganisasies in die suide finansieel van ryk noordelike skenkers afhanklik is. In die alledaagse praktyk gaan dit tog maar oor armoedebestryding, wat volgens hierdie skrywers ook strukturele armoede insluit.

Teenoor hulle realistiese standpdunt verkies ekself egter nog steeds die idealistiese ideaal van samewerking, aangesien dit 'n sleutelelement in egte ontwikkeling is. Armoedebestryding, soos onkruidbestryding, maak van die armes 'n objek. Hiermee word egter nie die probleme rondom samewerking geïgnoreer nie - 'n volgende belangrike punt.

\subsection{Ontwikkelingsamewerking bevraagteken}

Die ontwikkelingsgeskiedenis lewer talle voorbeelde op waar Afrika die Weste vir sy armoede beskuldig (vgl. byvoorbeeld Rodney, 1989) of omgekeerd, waar die Weste Afrika uitsluitlik self vir sy ekonomiese onderontwikkeling verantwoordelik hou. Sulke standpunte maak ontwikkelingsamewerking moeilik en selfs onmoontlik. Omdat Afrika vir sy ekonomiese ontwikkeling van noordelike finansiële hulp afhanklik is, word hier alleen aan die argumente téén hulp vanuit 'n 
Westerse hoek aandag gegee, asook die ekonoom, Sachs (2005), se antwoorde daarop.

\subsubsection{Vermeende redes waarom ontwikkelingshulp vir Afrika nie nodig is nie}

- Dit help nie om ontwikkelingshulp aan Afrika te gee nie, want dit lewer feitlik geen reslutate op nie

Hierop antwoord Sachs $(2005: 269,310)$ dat Afrika nie te veel ontwikkelingshulp nie, maar eerder te min ontvang het en nog steeds ontvang. In 2002 was dit slegs 30 biljoen VSA dollar, waarvan slegs 12 biljoen Afrika uiteindelik bereik het nadat al die verskuilde tussenkostes verhaal is.

\section{- Afrika is korrup}

Hierop is Sachs (2005:312) se antwoord dat Afrika se regerings swak is, omdat hulle ekonomies swak is. 'n Goeie regering lei wel tot beter ekonomiese groei, maar die omgekeerde is net so waar: 'n hoër inkomste kan ook tot beter regering lei. Daar is ook geen bewyse dat Afrikalande swakker regeer word en dus meer korrup is wanneer dit vergelyk word met baie ander arm lande oor die wêreld nie.

\section{- Afrika is ondemokraties}

Volgens Sachs (2005:315) is daar nie 'n regstreekse verband tussen outoritêre regerings en ekonomiese groei nie. China is ' $n$ voorbeeld in hierdie verband.

\section{- Ekonomiese onvryheid}

Volgens Sachs (2005:318) is die gedagte dat Afrika sal ontwikkel indien dit die kapitalistiese vryemarkekonomie volledig aanvaar, nog 'n voorbeeld van 'n magiese oplossing: "Economic freedom is definitely a plus for economic development, but alas, it is not a magic bullet" (Sachs, 2005:320). Ten spyte van 'n onvrye ekonomie het China die afgelope tyd geweldig ontwikkel, terwyl Switserland, nieteenstaande groot vryheid, 'n lae groeikoers het. Sachs staan dus 'n gemengde (nie 'n suiwer kapitalistiese of sosialistiese) ekonomie voor, waarin sowel die privaatsektor as die staat hulle verantwoordelikhede moet nakom.

\section{- Gebrek aan moraliteit}

Hierdie argument kom gewoonlik na vore in verband met die VIGSpandemie in Afrika. Dít word deur die Weste uitsluitlik toegeskryf 
aan die seksuele losbandigheid van die Afrikane. Wetenskaplike ondersoeke het egter bewys (vgl. Sachs, 2005:322) dat mense in baie ander wêrelddele, die Weste ingesluit, gemiddeld meer seksmaats het as in Afrika. Daar sal dus na nog ander redes gesoek moet word vir die vinniger verspreiding van die VIGS-virus in Afrika.

- Dit is sinloos om honger/siek kinders se lewens te red, want dan is daar net nog meer honger/siek volwassenes

Ook hierop het Sachs (2005:323) 'n reguit antwoord: Dit is reeds herhaaldelik deur die wêreld bewys dat die beste manier om bevolkingsgroei te bekamp, is om armoede te bestry. Groot gesinne kom meestal by arm mense voor wat nie die nodige gesondheidsorg geniet nie. Om verskeie redes (vgl. Sachs, 2005:323) daal die aantal kinders met ekonomiese vooruitgang.

\section{- Ekonomiese groei sal outomaties na Afrika versprei}

Die argument hier is dié van "the rising tide lift all boats". Indien Afrika se bootjie dus nie begin vaar nie, is dit sy eie skuld. Sachs argumenteer weereens oortuigend dat die proses van ekonomiese groei nie so eenvoudig is nie. Die eenvoudige feit van Afrika se geografiese isolasie (bv. baie Afrikalande wat nie oor bevaarbare riviere en hawens beskik nie) word in so 'n argument nie verreken nie.

\section{- Afrikane is nie kompeterend nie}

Volgens Sachs (2005:327 e.v.) word die hedendaagse kapitalistiese vryemarkekonomie sterk beïnvloed deur die sosiaal-Darwinistiese ideologie van kompetisie, stryd en die uiteindelike oorlewing van die sterkste. Terwyl die sosialisme (bv. kommunisme) alle kompetisie wou uitskakel, word dit deur die kapitalisme verabsoluteer. Volgens Sachs is nie net kompetisie nie, maar ook vertroue en samewerking essensiële voorwaardes vir ekonomiese groei.

Sachs is dus oortuig dat ontwikkelingsamewerking 'n sine qua non is. Ook Bruwer (1994:71) beklemtoon twee vereistes: behalwe 'n innerlike wil by arm mense self, is toetrede van buite ook noodsaaklik, want arm mense in 'n put van magteloosheid en hopeloosheid wag op 'n redder.

Dié "redder" van Afrika staan ongelukkig nie meer slaggereed nie 'n volgende punt. 


\subsubsection{Ontwikkelingsamewerking in 'n krisis}

Soos duidelik uit onder andere die geskrifte van Verbeek (2005), Buijs (2001) en Van der Walt (2006b) blyk, beleef ontwikkelingsamewerking vandag 'n krisis en ontwikkelingshulp het afgeneem.

Buijs onderskei drie kante in dié krisis, naamlik ten opsigte van die motiewe vir ontwikkelingshulp; ten opsigte van die metodes en ten opsigte van die resultate (vgl. Buijs, 2001:24-33). Slegs kortliks iets oor elkeen van die drie.

\section{- Motiewe}

Onder motiewe onderskei Buijs, behalwe goeie motiewe (bv. die geregtigheidsmotief) ook die meestal bedekte verkeerde motiewe (bv. die blote politieke of ekonomiese eiebelang van mense of lande wat ontwikkelingswerk finansier). Dit wil lyk asof laasgenoemde minder goeie soort motiewe, as gevolg van die heersende neokapitalistiese ideologie, vandag 'n oorheersende rol begin speel.

\section{- Metodes}

Wat die metodes van ontwikkelingsamewerking betref, vestig Buijs die aandag op die hedendaagse aandrang van die donateurs dat die ontwikkelingsteun die nodige resultate moet oplewer. Dit is egter baie moeilik om te bepaal watter soort kriteria toegepas moet word om te bepaal of 'n ontwikkelingsprojek geslaagd is al dan nie. Buijs vestig verder die aandag op verkeerde verhoudings tussen die gewer(s) en die ontvanger(s) van ontwikkelingshulp. Werklike, wederkerige ontwikkelingsamewerking tussen die verskillende partye is volgens hom nog nie gerealiseer nie.

\section{- Resultate}

Ten slotte kom die resultate (van die motiewe en metodes) onder die loep. Probleme hier is dat na 50 jaar die resultate in die armer lande nie baie sigbaar en dus bemoedigend is nie. Wat wel duidelik blyk, is dat ontwikkelingshulp aan die armes dikwels afhanklikheid (hulpverslawing) tot gevolg het en dus hulle eie inisiatief en verantwoordelikheidsbesef ondergrawe. Sulke ontwikkeling is dus ook nie volhoubaar nie en stort in duie sodra die hulp onttrek word.

In die verdere verloop van die artikel sal na hierdie drie probleemvlakke teruggekeer word. (Die metodes en resultate by die behandeling van die vennootskapsmodel, is onder 6.1 e.v., en die motiewe of norme is aan die einde onder 7.2.4.) Om 'n vollediger beeld van 
die vraagstuk te kry, word nog eers gelet op die leemtes in die huidige opset.

\subsubsection{Leemtes in die samewerkingsketting}

Die "Ontwikkelingsamewerkingsketting" (vgl. Verbeek, 2005:93) dui 'n komplekse proses aan, waarby die volgende partye betrokke kan wees: die gegoede finansierders/donateurs/skenkers/gewers, wat die fondse voorsien; en die hoofsaaklik noordelike nieregeringsorganisasie, wat die fondse bestuur en na die suidelike NRO's kanaliseer, wat die steun ontvang en dit op mikro-, meso- en makrovlak tot voordeel van 'n bepaalde behoeftige doelgroep moet aanwend. In hierdie hele uitgerekte proses kan daar talle haakplekke voorkom.

Verskillende skrywers vestig die aandag onder andere op die volgende:

- Die armes self sit meestal nie aan die onderhandelingstafel waar oor hulle probleme gepraat word nie, maar word deur iets ('n verslag) of iemand (wat oningelig mag wees) verteenwoordig. Wat die rykes te hore kom oor die armes se behoeftes het dus reeds deur verskillende "filters" van verslae, vergaderings en ander mense se persepsies gegaan.

- Ontwikkelingsorganisasies het die belangrike taak om die armes (die doelgroep) te help deur ook die armes se stem te laat hoor, deur vir hulle as voorspraak op te tree. Daar bestaan egter die gevaar van "hijacking the voice of the poor". Die noordelike NRO's stry op die oog af vir die armes, maar op die keper beskou is dit dikwels hulle eie visies, interpretasies en belange wat die deurslag gee.

- Die vraag is selfs hoe naby die plaaslike NRO's nog aan die wêreld van die armes staan. Hulle hoort immers tot 'n groep wat nie meer bitter armoede ervaar nie. Dié groep is gewoonlik ook nie die grootste kampvegters van maatskaplike verandering ter wille van groter geregtigheid nie.

- 'n Volgende probleem is die hulpverlener(s) in die Noorde. Hierdie rykes kyk met 'n bepaalde bril wat deur hulle eie kultuur en omstandighede gekleurd is na die problematiek van die armes daar ver in die Suide. Die gevolg is dat daar weinig sprake kan wees van wederkerigheid in hierdie proses. Die ontwikkelingspraktyk het nog steeds te make met ou koloniale stereotipes: die "self" (Weste) word geassosieer met ontwikkeling en dus meerderwaardigheid en die "ander" (Suidelike armes) met agterge- 
blewenheid, 'n tekort aan kennis en selfs moraal - die minderwaardiges. Oor die algemeen toon die ryk skenkers te min respek vir die kulturele waardes van die armes.

- Nog 'n drumpel wat oorgesteek moet word, is die inherente wanbalans in die verhouding tussen die gewers van geld en goedere in die Noorde en die ontvangers daarvan in die Suide. Geld beteken gewoonlik mag. Eintlik is sowel die noordelike skenkers as die suidelike NRO's verantwoording aan die doelgroep, wat hulle wil dien, verskuldig. In praktyk word egter as gevolg van 'n hiërargiese gesagsbeskouing - gesag van bo-na-onder - alle gesag by die skenkers geplaas en die verantwoordelikheidsplig alleen op die suidelike NRO's. Die ryk noordelike skenkers sluit gewoonlik ook een of ander kontrak met die Suide om sekere doelstellings (resultate) te bereik. Wie betaal, sal ook bepaal!

- Verskillende magsfaktore kan die verhouding skeeftrek, sodat dit nie meer aan die vereistes van 'n werklike vennootskap voldoen nie.

- Die noordelike NRO's tree gewoonlik as die "onderwyser" op, terwyl die suidelikes die "leerlinge" moet wees. "Accept our funds, accept our training" is die veronderstelling. Dit is egter ' $n$ ongewone situasie wanneer een vennoot 'n ander probeer ontwikkel. 'n Werklike vennootskap (vgl. hieronder) veronderstel tog gelykheid, wederkerigheid, uitruil van kennis, om na mekaar te luister en van mekaar te leer. Gewoonlik is die ideaal van die Noorde vir die Suide dat hulle deur middel van die kapasiteitsbou onafhanklik en ook finansieel selfvoorsienend sal word. Wanneer dié punt bereik word, wat egter selde die geval is, word die vennootskap, ironies, vanaf die kant van die Noorde beëindig.

In 'n onderhoud met Tol (2006:24) herbeklemtoon Verbeek dat die ondersoek na oorsake en moontlike oplossings (teorievorming) asook die doel, rigting, tempo en resultaat van ontwikkelingsamewerkingsprojekte in die Suide nog té veel eensydig deur die noordelike "maghebbers" bepaal word. Sy slotwoord aan die lesers is:

In de eerste plaats: hoor de stem van het Zuiden en luister ernaar. Willen we werkelijk openstaan voor de ander of regelen wij het vooraf zelf? Laten wij ook kritiek toe van hen op ons? (Tol, 2006:25.) 


\subsubsection{Vrugtelose oor-en-weer beskuldigings}

Hierdie meer prinsipiële probleme lei in die praktyk tot baie praktiese probleme en selfs beskuldigings tussen die ontvangers en skenkers van ontwikkelingshulp soos byvoorbeeld die volgende (vgl. Hoksbergen, 2003:4-5):

- Vanaf die kant van die ontvangers bestaan daar vele klagtes soos die volgende: die skenkers gee wel mildelik, maar met 'n neerbuigende houding (want die werklike mag lê by hulle); die ontvangers weet byvoorbeeld dat hulle grootste behoefte tersiêre onderwys is, maar die donateurs help nie daarmee nie, en hulle is dus genoodsaak om maar by die skenkers se planne te moet inval; die ontvangers ervaar die donateurs as veeleisend, onbuigsaam en bemoeisiek; die voortdurende (terug)rapportering laat die ontvangers ook vermoed dat hulle nie ten volle vertrou word nie; bowendien verstaan die donateurs nie die plaaslike kulturele gewoontes nie en wend ook geen poging aan om dit beter te begryp nie. Die volgende sou ook hier bygevoeg kon word: die armes wil nie jammerhartigheid ontvang nie, maar respek en erkenning van hulle menswaardigheid (vgl. Bruwer, 1994:35). Verder verlang hulle ook deursigtigheid. Indien dit nie die geval is nie, word dit, soos slegte kos, onverteerbaar en dus verwerp (Bruwer, 1994:35).

- Vanaf die kant van die (meestal) noordelike skenkers word onder andere die volgende kritiek teen hulle suidelike medewerkers uitgespreek: dit is nie duidelik of die suidelike vennote wel die nodige toewyding aan die ontwikkelingswerk (waarop die noorde besluit het) openbaar nie; die ontvangers is blykbaar meer geïnteresseerd in hulle salarisse, voertuie en om hulle eie familie in poste aan te stel; hulle stel wel beheerliggame aan om oor ontwikkelingsprojekte toesig te hou, maar dit gebeur heelwaarskynlik bloot om die donateurs tevrede te stel; die doel wat die hulpverleners nastreef, is dat die ontvangers oor 'n tydperk selfonderhoudend sal word en die projekte volhoubaar, maar hulle bemerk nie veel inisiatief in dié rigting nie - die ontvangers tree eerder op asof die hulpverleners vir altyd die werk sal finansier.

Hoe kan hierdie situasie verbeter word? Dalk bied die idee van 'n vennootskap 'n antwoord. 


\section{Die vennootskapsmodel}

Om die verhouding tussen gewers en die ontvangers van hulp te verbeter, word in die lig van genoemde probleme in die jongste tyd groot klem gelê op die idee van 'n vennootskap. So 'n vennootskap kan die verhouding van begunstiger-kliënt, skenker-ontvanger en leermeester-leerling vervang.

Een van die G8 se Millennium doelstellings is byvoorbeeld om 'n globale vennootskap vir ontwikkeling tot stand te bring. President Mbeki se program vir die opheffing van Afrika (New Partnership for Africa's Development - NEPAD) lê ook daarop klem dat ontwikkeling nie eensydig vanuit die Noorde kan geskied nie - dit moet in 'n egte vennootskapsverhouding gebeur.

\section{1 'n Definisie}

Verbeek omskryf 'n vennootskap soos volg:

Partnership word ... gezien als een vorm van samenwerking gebasseerd op wederzijds respect, ownership, en de eigen verantwoordelijkheid van een ieder. Daarbinnen wordt gezocht naar zoveel mogelijk gelijkwaardigheid en erkenning van wederzijdse afhankelijkheid in het ontwikkelingsgebeuren, ondanks duidelijke asymetrie in toegang tot macht en middelen. Wat dit laatste betreft speelt de aard van de overeenkomst tussen beide partijen een cruciale rol ... (Verbeek, 2005:95).

Vereenvoudigd sou 'n mens kon sê dat die gangbare prosedure is dat die donateurs se befondsing tot voorafbeplande programme/projekte lei wat ten slotte ook tot 'n sekere verhouding tussen die Noorde en die Suide kan lei. Dit sou 'n groot verbetering wees indien dié proses omgekeer kon word, naamlik dat die verhouding die belangrikste is en daarna kom die nood wat aandag moet ontvang waarvoor die gewers ten slotte die geld moet voorskiet.

Is die suidelike armes dan nie van die noordelike donateurs afhanklik nie? Verbeek (2005:240) dink nie so nie. Die noordelike vennoot beskik oor die investeringskapitaal en die suidelike oor die menslike uitvoeringskapitaal. Albei vorme van "kapitaal" is nodig en is vir goeie resultate van mekaar afhanklik. Dit is belangrik om hierdie wedersydse afhanklikheid teenoor mekaar te erken en in die praktyk uit te leef.

So 'n vennootskapsverhouding moet egter aan heelwat vereistes voldoen. 


\subsection{Belangrike vereistes vir'n werklike vennootskap}

Voortbouend op Hoksbergen (2003:12-18), is die belangrikste vereistes vir 'n egte ontwikkelingsamewerkingsvennootskap die volgende:

\subsubsection{Plaaslike wortels}

Die meeste plaaslike NRO's het hulle ontstaan te danke aan die feit dat fondse vanuit die Noorde, of in alle geval "van buite", beskikbaar was. Die ideaal dat die suidelike vennote uiteindelik selfstandig en selfonderhoudend (volhoubaar) sou word, het egter selfs na dekades selde gerealiseer. Daarom is dit veel beter dat moontlike donateurs in die buite- én binneland aansluit by reeds bestaande plaaslike inisiatiewe, dit wil sê mense met 'n visie, wat ook ander geïnspireer het om op ' $n$ vrywillige wyse en sonder vergoeding vir 'n bepaalde doel saam te werk. In so 'n geval sal die plaaslike NRO's eerder werk vir 'n visie as vir 'n salaristjek. Waarskynlik sal daar ook 'n beter organisatoriese struktuur en verantwoordingsin wees en sal die NRO's ook groter geloofwaardigheid binne hulle gemeenskap geniet.

Onder hierdie punt sou ook weer beklemtoon kon word dat 'n wesenlike faset van 'n vennootskapsbenadering 'n ernstige omgang met die kultuur, lewensvisie en lewensvorme van nie alleen die Weste nie, maar veral van die mense van Afrika is (vgl. Van der Walt, 1999; 2001 en 2003).

\subsubsection{Werk na 'n verhouding van gelykheid}

Soos reeds gesê, neig die eensydige befondsing vanuit die Noorde (dit geld ook vir plaaslike skenkers) tot 'n verhouding van ongelykheid: 'n meerderwaardige gewer teenoor die vernederende posisie van ontvanger van "liefdadigheid". So 'n situasie kweek byna vanselfsprekend afhanklikheid en gelatenheid ("dancing the tune of the donor"). 'n Werklike vennootskap veronderstel gelykheid in stem, respek, gesag en nog meer.

Om hierdie doel te bereik, beveel Hoksbergen (2003:14) praktiese stappe aan soos die volgende: minder regstreekse befondsing van die Noorde en meer eie bydraes vanuit die Suide; gesamentlike besluitneming; groter sensitiwiteit vir mekaar se opinies; vertroue en wedersydse respek; gereelde en duidelike kommunikasie en nog talle ander. 


\subsubsection{Suit'n ooreenkoms - nie 'n kontrak nie}

Die meeste ontwikkelingsamewerkings vertoon die karakter van 'n kontrak. Daarin word die finansiering, projekte, verpligtinge en verwagte resultate noukeurig uiteengesit. Hierdie soort ooreenkomste word egter al meer bevraagteken, aangesien dit noordelike oorheersing en suidelike gelatenheid bevorder. Daarom word daar wegbeweeg na soepeler vennootskapsooreenkomste.

\subsubsection{Werk saam}

Die aandag is reeds daarop gevestig dat mense in die Suide (ook in Afrika) tradisioneel groter waarde aan verhoudings as aan geld toeken. Om sáám te werk is een van die beste maniere om verhoudings te bou. Die aksent moet dus verskuif van die standaardpatroon, naamlik dat die Noorde die geld voorsien en die Suide die werk doen. Die noordelike donateurs en NRO's kan op verskillende maniere nouer by die konkrete werk in die Suide betrokke raak.

\subsubsection{Kanaliseer die stem van die Suide}

Die neiging by noordelike NRO's is dikwels om vir die armes te praat eerder as om slegs as kanaal vir die stem van die armes te dien. Om laasgenoemde te bereik is gereelde persoonlike kontak op voetsoolvlak egter nodig. Die armes se gesigte moet gesien en hulle stemme gehoor word. Om só saam te werk kan ook veel groter geloofwaardigheid verleen aan die voorspraak wat NRO's in die Noorde vir die suidelike armes moet maak.

\subsubsection{Gesamentilike befondsing}

Aangesien dit onrealisties is om te dink dat die gaping tussen ryk en arm spoedig gaan verdwyn, is dit ook nie realisties om te dink dat die noodsaak van ontwikkelingsamewerking sal ophou nie. Die werklike probleem is om sowel buitensporige kontrole vanuit die Noorde as 'n gebrek aan verantwoording by die Suide op te los. Sommige beweer dat die Noorde alle befondsing moet stop. 'n Ander ekstreme standpunt is dat die Noorde eenvoudig alles moet finansier.

'n Middeweg mag egter die beste oplossing bied, naamlik dat projekte gesamentlik befonds moet word. Hoksbergen (2003:16) is van mening dat die suidelike vennote ten minste vir die beginkostes en veral vir die salarisse van hulle eie personeel verantwoordelik moet wees. Dit beteken egter nie dat albei partye ewe veel in 'n projek moet belê nie. 


\subsubsection{Uitfasering is nie gewens nie}

Tradisioneel word ontwikkelingsamewerking as 'n tydelike saak beskou: wanneer die werk afgehandel is, loop die verhouding ook ten einde. Die hoofargument daarvoor was om die afhanklikheidsindroom te voorkom. Dit maak egter nie veel sin om 'n verhouding, wat met soveel tyd, moeite en geld opgebou is, te beëindig nie. Dit pas ook nie by die kultuur van die Suide nie, want hulle beskou die vennootskap self as deel van die ontwikkelingsproses. Wat meer is, is dat

For development issues that are global as well as local, we need to develop civil society organizations that build a sense of community, or social capital, on a global scale. What better way to do this than to build lasting partnerships amongst like-minded organizations from South and North? (Hoksbergen, 2003:17.)

\subsubsection{Evaluering van die vennootskap self}

Die gangbare gebruik is om die groei in die kapasiteit van die suidelike NRO's en die teikengroep (armes) te evalueer en om te besluit of die doelstellings met die verskillende programme/projekte bereik is. Selde egter word die verhouding self krities geweeg. Indien die bou van 'n Christelike organisasie of gemeenskap met invloed op die breëre burgerlike samelewing egter 'n belangrike deel van die totale doelstelling is, moet nie alleen die werk op grondvlak gemeet en NRO's versterk word nie, maar ook gereeld na die vennootskap self gekyk word. Dit impliseer dat die vennote ook daarvoor oop sal wees om wedersyds deur mekaar geëvalueer te word.

\subsubsection{Nie die enigste weg nie}

Uit bostaande uiteensetting blyk dat 'n egte vennootskap groot ooreenkoms in identiteit, onderliggende (geloofs)waardes en missie veronderstel. Daarom kan nie enige werksverhouding as 'n vennootskap beskou word nie.

Die voorafgaande beteken dus nie dat 'n vennootskapsverhouding as die nuwe panasee vir alle probleme in ontwikkelingsamewerking beskou moet word nie. ' $n$ Vennootskap is ook nie noodwendig altyd die beste ontwikkelingsamewerkingsverhouding nie.

Hoksbergen (2003:18) noem daarom ook ander verhoudings soos "collaboration, cooperation, alliances, consortia, networks or joint ventures". Die verhouding tussen 'n groot internasionale donateur, 'n 
NRO uit die Noorde, 'n plaaslike NRO en die plaaslike regering met die doel om byvoorbeeld skoon drinkwater aan 'n streek te verskaf, sal eerder 'n "cooperative venture" genoem kan word. Omstandighede bepaal dus ook watter soort samewerkingsmodel die mees gepaste en effektiefste sal wees.

\subsubsection{Breëre toepassingsmoontlikhede}

Tot sover is meestal net van internasionale ontwikkelingsamewerking tussen vennote, wat geografies ver uitmekaar (die Noorde en die Suide) geleë is, melding gemaak. Dit beteken nie dat wat hier bepleit word, nie ook nasionaal en plaaslik van toepassing kan wees nie. Kerke, sake-ondernemings, welsynsorganisasies en selfs individue in dieselfde land en omgewing behoort by die ontwikkeling van hulle eie armes betrokke te wees. Dié soort werk word byvoorbeeld beskryf in die werk van Perkins. Hoewel hy nie die woord "vennootskap" gebruik nie, blyk dit uit alles wat hy sê (vgl. Perkins, 1993:64-71) dat hy iets soos 'n vennootskap as een van die geheime van geslaagde gemeenskapsontwikkeling beskou. Daarom beklemtoon Perkins ook dat sulke werk nie "op 'n afstand" gedoen moet word nie. Hoe nader aan die armes, hoe meer outentiek, geloofwaardig, geslaagd en volhoubaar is die werk.

Terwyl uit die voorafgaande alreeds duidelik geword het wat die waarde van 'n vennootskap kan wees, word dit nou meer eksplisiet genoem.

\subsection{Die waarde van 'n vennootskap}

- Plaaslike impak: Indien donateurs nie meer deur die ontvangers nie, maar saam met hulle werk, kan projekte groter doeltreffendheid ervaar. Albei partye se sterk kante word dan benut - ook dié van die Suide, wat die plaaslike kultuur beter ken en die projekte as hulle eie sal aanvaar. 'n Outentieke in plaas van 'n paternalistiese vennootskap en gepaardgaande eienaarskap in die Suide, is volgens Hoksbergen ook 'n belangrike dryfveer vir die ontvangers om resultate te lewer.

- Waarde vir die burgerlike samelewing: Met 'n ware vennootskap en plaaslike eienaarskap word die probleem van 'n geringe impak op die burgerlike samelewing ook hanteer. Burgers word bemagtig om aan politiek-sosiaal-ekonomiese prosesse deel te neem en dit te beïnvloed. Dit kan nie gebeur wanneer hulle plaaslike geworteldheid bevraagteken word, hulle stemme dus swak en hulle impak minimaal is nie. Wanneer die donateurs nie 
domineer nie, maar slegs die plaaslike prosesse fasiliteer, versterk hulle dus nie net die plaaslike NRO's nie, maar ook die breëre burgerlike gemeenskap.

- Globale ontwikkeling: Die derde rede ten gunste van vennootskappe is dat dit in ontwikkeling vandag om meer as net 'n plaaslike gemeenskap gaan. Wêreldwyd bestaan vandag dieselfde probleme waarvoor die Noorde en Suide sáám oplossings behoort te soek. Eensydige besluite en oplossings mag op die korttermyn die maklikste wees en dalk ook werk, maar dit saai die saad vir dieper en groter probleme in die toekoms.

- 'n Koninkryksgemeenskap: Dit gaan nie net daaroor om probleme op te los en invloed op die omgewing te hê nie, maar ook om 'n gemeenskap van Christene tussen Noord en Suid te bou. Die meer taakgeoriënteerde en individualistiese Westerlinge begin gewoonlik met die werk om eers later aan so 'n gemeenskap te dink. Vir die mense van die Suide, Afrikane ingesluit, met hulle sterk gemeenskapsgevoel (vgl. Van der Walt, 2003:133 e.v.) is presies die omgekeerde weg egter belangrik. So 'n koninkryksgemeenskap kan alleen gebou word deur tussen die armes te wees en nie deur bokant hulle te staan nie.

\subsection{Geen "magic bullet" nie}

Die vennootskapsidee is nie iets splinternuuts nie. In die lig van Sachs (2005:255) se bevindings, moet ook onthou word dat daar nie één "magic bullet" bestaan om ontwikkeling te laat plaasvind nie. Die vennootskapsmodel moet dus nie in isolasie nie, maar sáám met ander belangrike insigte in ontwikkelingswerk toegepas word.

Soos in die geval van talle ander voorstelle vir geslaagde ontwikkelingswerk, sal 'n groot struikelblok in hierdie geval ook wees dat die "omgewing" in die breë sin van die woord nie altyd gunstig is vir die implementering van die vennootskapsmodel nie. In byvoorbeeld die afwesigheid van 'n gunstige, gesonde politieke klimaat met onnodige inmenging van die kant van regerings en gepaardgaande korrupsie, is ook so 'n aanpak by voorbaat tot mislukking gedoem.

\section{Slot die burgenlike samelewing en die bydrae van 'n reformatoriese perspektief}

Hierbo is egter reeds aangetoon (vgl. 6.3) dat die vennootskapsmodel juis kan bydra om die burgerlike samelewing of maatskaplike 
middelveld te versterk en hierdeur dominering vanuit die politiek of ekonomie teë te werk. lets meer moet daaroor gesê word.

\subsection{Die belangrike rol van die burgerlike samelewing}

Die begrip civil society dui op 'n samelewing met veel meer verbande as net die politieke of ekonomiese. Teenoor die slagspreuk dat "alles net politiek/ekonomie is", stel dit duidelik "politiek/ekonomie is nie alles nie". Anders gestel: die begrip dui nie op die makro- of mikrovlak nie, maar op die mesovlak tussen eersgenoemde twee.

Terwyl Buijs (2006:19-41) 'n deeglike historiese en prinsipiële uiteensetting bied van wat die begrip "burgerlike samelewing" behels, toon Son (1999:184 e.v.) aan hoe 'n belangrike rol allerlei vrywillige groepe en organisasies vanuit die burgerlike samelewing in die ekonomiese ontwikkeling van Suid-Korea die afgelope dertig jaar gespeel het. Hulle bemagtig die burgers en sorg dat die regering sy werk goed doen en nie sy grense oorskry nie.

... civil society is reckoned as one of the most important forces in Korean society ... Politicians and businessmen watch civic groups more closely than anything else, since these groups can easily mobilize voters and consumers to hurt them badly. (Son, 1999:185.)

Ook Hamelink en Visser $(2002: 17,107)$ sê dat die rol van maatskaplike organisasies by die ontwikkeling van 'n land nie genoeg benadruk kan word nie. Owerhede behoort hulle ook groter vryheid te gun. Na skatting was daar reeds in 2000 ongeveer 35000 sulke organisasies in ontwikkelende lande werksaam. Dit is tyd dat die mense van (Suid-)Afrika ook die waarde van 'n goed georganiseerde burgerlike samelewing besef en nie alles van die politiek(staat) verwag nie.

\subsection{Die bydrae vanuit'n Reformatoriese samelewingsfilosofie}

Tussen die huidige klem op die belangrikheid van 'n burgerlike samelewing en 'n Reformatoriese samelewingsfilosofie is daar groot ooreenkoms. Albei verwerp totalitarisme en lê klem op die selfstandigheid van 'n verskeidenheid verbande in die samelewing. ' $\mathrm{Re}$ formatoriese samelewingsvisie kan verder ook 'n belangrike bydrae lewer tot die ontleding en verheldering van verskillende ontwikkelingsamewerkings, ingesluit dié van 'n vennootskap. 


\subsubsection{Wat dit inhou}

Dit is merkwaardig dat, terwyl ontwikkeling op die verandering van die menslike samelewing gerig is, die meeste werke op hierdie gebied selde of dikwels net oppervlakkige beskouings oor die mens en die samelewing bevat. Die mensvisie kan egter verbreed en verryk word deur die Reformatoriese filosofie se modaliteitsleer, wat ten minste vyftien aspekte/funksies by die mens onderskei.

Volgens 'n Reformatoriese samelewingsfilosofie (soos onder andere ontwikkel deur Dooyeweerd, 1957 en 1986; McCarthy et al., 1982 en Skillen \& McCarthy, 1991) word 'n verskeidenheid samelewingsverbande, elk met 'n eie aard, norm, unieke taak, eiesoortige ampte en gesag erken. Hierdie samelewingsverbande is veel meer as blote "kontrakte" tussen individue/groepe soos by die liberalisme en ook nie blote "onderdele" van 'n groter geheel soos in die geval van die kollektivisme of kommunalisme nie, maar soewerein op eie gebied. Terselfdertyd staan hulle ook nie geïsoleerd van mekaar nie.

Volgens hierdie samelewingsfilosofie verskil menslike verbande van mekaar omdat hulle leidende of kwalifiserende funksies verskil. 'n Kerk word byvoorbeeld deur geloof gekwalifiseer, 'n bedryf is 'n ekonomiese saak, die huwelik moet deur etiese norme (trou) gelei word en 'n staat word deur die juridiese (algemene geregtigheid) gekwalifiseer.

\subsubsection{Verskillende take}

Indien hierdie soort analise op die verskillende vorms van ontwikkelingsamewerking toegepas word, mag dit verhelderende perspektiewe bied. Die samewerking tussen twee state is heelwaarskynlik van politieke aard. Donateurs se werk is weer meer ekonomies gekwalifiseerd. Hoe sou 'n mens die verhouding tussen noordelike en suidelike vennote tipeer? Of die verhouding tussen 'n plaaslike NRO en die teikengroep (armes)? Dit hang af van wat die doel met die ontwikkelingswerk is. Is dit byvoorbeeld primêr voedselvoorsiening of landbou, werkskepping, die bevordering van handel, opleiding en onderwys, omgewingsbewaring, menseregte, goeie bestuur, konflikhantering, vlugtelingversorging?

Hamelink en Visser (2000:136 e.v.) gee 'n voorbeeld van hoe daar volgens 'n Reformatoriese samelewingsfilosofie tussen 'n verskeidenheid take onderskei kan word. Hulle maak eers 'n duidelike onderskeid tussen die verantwoordelikhede van 'n staat, maatskaplike organisasies en multinasionale organisasies (soos die Wêreld- 
bank, IMF, VN en WHO) en in ooreenstemming daarmee bied hulle riglyne vir samewerkingsontwikkeling vir elkeen van die drie.

\subsubsection{Verskil in amp, gesag, mag en verantwoordelikheid}

Vroeër in hierdie artikel het geblyk dat gesag, mag en verantwoordelikheid sleutelprobleme in enige vorm van ontwikkelingsamewerking is, insluitende 'n vennootskap. Hoewel ruimte dit nie toelaat om die Reformatoriese visie op hierdie begrippe (insluitend amp as diens) toe te lig nie, kan gekonstateer word dat dit ook in hierdie opsig 'n belangrike bydrae kan lewer (vgl. Van der Walt, 2006c:137146). Amp, gesag, mag en verantwoordelikheid word bepaal deur die aard en taak van 'n spesifieke verband en is dus altyd gekwalifiseerd en beperk en kan dus nie oral op dieselfde manier uitgeoefen word nie. In die lig van die tiperende of kwalifiserende element van 'n samelelwingsverband (vgl. 7.2.1) sal dus op die mees gepaste vorm van gesag, mag en verantwoordelikheid vir 'n spesifieke samewerkingsooreenkoms besluit moet word.

\subsubsection{Verskillende norme}

Ook ten opsigte van die groot onduidelikheid in verband met norme vir ontwikkelingswerk (vgl. byvoorbeeld Gasper, 2004 en Goudzwaard \& De Lange, 1995:39) kan 'n Reformatoriese samelewingsfilosofie meer lig bied. So 'n samelewingsfilosofie gaan uit van die basiese gedagte dat alles wat die mens doen, ook ontwikkelingswerk, religieus bepaald is, 'n diens aan God of 'n afgod. Hierdie diens moet geskied in ooreenstemming met die sentrale gebod van liefde tot God en die naaste (Matt. 22:37-40 en talle ander plekke in die Bybel). Die liefde moet egter in eiesoortige norme vir elke menslike verband gepositiveer (konkreet gemaak) word. So byvoorbeeld kom liefde in die huwelik tot vergestalting in wedersydse trou, in die kerk in broederlike/susterlike liefde, in die staat in die vorm van openbare geregtigheid. Hoe kan die sentrale liefdesgebod vir die terrein van ontwikkelingsamewerking, wat armoede wil verlig, gepositiveer word?

Omdat ook hierdie soort werk nie religieus neutraal (sekulêr) is nie, kan eers gevra word watter norme in die verhouding tot God en daarna in verhouding tot die medemens en die natuur moet geld.

- Teenoor God sou drie norme, waardes of deugde genoem kon word: Eerstens gehoorsaamheid aan sy gebod dat daar geen armes onder ons mag wees nie (Deut. 15:4). Dit impliseer bereidheid om die gawes wat 'n mens van Hom ontvang het aan 
te wend vir die behoeftes van jou medemens - vrywillig, sonder voorbehoud of verwagting van vergoeding (vgl. 2 Kor. 8:15). Tweedens dankbaarheid, omdat alles wat ons besit 'n geskenk van God is. Derdens vergenoegdheid met dít wat 'n mens het.

- Teenoor die arm medemens sou die volgende vier norme onderskei kon word: Eerstens wedersydse respek, omdat ons almal na die beeld van God geskep is. Tweedens barmhartigheid, veral teenoor die eerste kategorie armes (vgl. 3.3), naamlik die ekonomies armes. Derdens geregtigheid teenoor die tweede kategorie, die magteloses. Vierdens bewoënheid teenoor die derde kategorie van die geestelik arme (wat ook die materieel ryke, maar nogtans geestelik arme insluit).

- Teenoor die res van die skepping: Uit die kultuurmandaat aan die mens (Gen. 2:15) blyk dat die mens se taak is om sy omgewing te beskerm, op te pas en te versorg. Daarom praat Goudzwaard en De Lange (1995 - vgl. die subtitel van hulle boek) van 'n ekonomie van sorg of omgee.

Die meeste van hierdie norme geld primêr vir die rykes, maar dit mag nie tot hulle beperk word nie.

Indien aan hierdie norme beantwoord word, kan die verdeelde wêreld (waarmee hierdie artikel begin het) 'n beter gedeelde wêreld word. 'n Heeltemal geheelde wêreld sal ons menslike pogings tot armoedebestryding egter nie bereik nie (vgl. Deut. 15:11 en Mark. 14:7). Die feit dat ons altyd die armes by ons sal hê, word in God se Woord egter nie genoem as 'n verskoning vir die rykes om niks daaraan te doen nie, ook nie as 'n fatalistiese aanvaarding van die armes wat in hulle lot berus nie. Inteendeel, dit behels 'n oproep tot daadwerklike optrede van ryk en arm - ook vir ons Afrikakontinent.

\section{Geraadpleegde bronne}

BOERSMA, C. s.a. The poor side of Europe: the church and the (new) poor of Western Europe. Geneva: World Council of Churches.

BRUWER, E. 1994. Beggars can be choosers: in search of a better way out of poverty and dependence. Pretoria: University of Pretoria. (Institute for Missiological and Ecumenical Research.)

BUIJS, G.J., red. 2001. Als de olifanten vechten: denken over ontwikkelingssamewerking vanuit Christelijk perspectief. Amsterdam: Buijten \& Schipperheijn.

BUIJS, G.J. 2006. The promises of civil society. (In Blokhuis, P. \& Hielema, E.K., eds. Civil society: East and West. Sioux Center: Dordt College Press. p. 19-42.) 
DICKINSON, R.D.N. 1983. Poor, yet making many rich: the poor as agents of creative justice. Geneva: World Council of Churches.

DOOYEWEERD, H. 1957. A new critique of theoretical thought. Vol. 3. Amsterdam: The Presbyterian and Reformed Publishers.

DOOYEWEERD, H. 1986. A Christian theory of social institutions. La Jolla: The Herman Dooyeweerd Foundation.

DU PISANI, J. 2007. Nuwe wyn in ou sakke? Hoe die morele grondslag van volhoubare ontwikkeling geskuif het. Koers, 72(2):193-218.

GASPER, D. 2004. The ethics of development: from economism to human development. Edinburgh: Edinburgh University Press.

GOUDZWAARD, B. \& DE LANGE, H. 1995. Beyond poverty and affluence: toward an economy of care with a twelve-step program for economic recovery. Grand Rapids: Eerdmans.

HAMELINK, M. \& VISSER, C. 2002. Gedeelde wereld: armoedebestrijding en Christelijk politiek. s.I: Prinsterer Stichting.

HENGEL, M. 1974. Property and riches in the Early Church: aspects of a social history of early Christianity. Philadelphia: Fortress.

HOKSBERGEN, R. 2003. Partnership for development: why it is so important, why it is so hard, how to go about it. Reformed Ecumenical Council Focus, $3(4): 3-21$.

JENKINS, P. 2002. The new Christendom: the coming of global Christianity. New York: Oxford University Press.

JENKINS, P. 2006. The new faces of Christianity. New York: Oxford University Press.

JONGENEEL, R. 2006. End of poverty: sociale gerechtigheid in een mondiaal perspectief. Beweging, 70(3):22-25.

MCCARTHY, R., OPPEWAL, D., PETERSON, W. \& SPYKMAN, G., eds. 1982. Society, state and schools: a case for structural and confessional pluralism. Grand Rapids: Eerdmans.

MYERS, B.L. 2001. Walking with the poor: principles and practices of transformational development. Maryknoll: Orbis.

PERKINS, J.M. 1993. Beyond charity: the call to Christian community development. Grand Rapids: Baker.

RIST, G. 1999. The history of development: from Western origins to global faith. London: Zed.

RODNEY, W. 1989. How Europe underdeveloped Africa. Harare: Zimbabwe Publication House.

SACHS, J.D. 2005. The end of poverty: economic possibilities for our time. New York: Penguin.

SAMUEL, V. \& SUGDEN, C., eds. 1987. The church in response to human need. Grand Rapids: Eerdmans.

SCHROTENBOER, P.G. et al. 1978. And He had compassion on them: the Christian and world hunger. Grand Rapids: Christian Reformed Church.

SCHUURMAN, E. 2005. The technological world picture and the ethics of responsibility. Sioux Center: Dordt College Press.

SEN, A. 1999. Development as freedom. New York: Anchor.

SIDER, R.J. 1977. Rich Christians in an age of hunger: a Biblical study. London: Hodder \& Stoughton.

SKILLEN, J. \& MCCARTHY, R.M., eds. 1991. Political order and the plural structure of society. Atlanta: Scholars Press. 
SON, B.H. 1999. Relevance of sphere sovereignity to Korean society. (In Van der Kooi, C. \& De Bruijn, J., eds. Kuyper reconsidered: aspects of his life and work. Amsterdam: V.U. Uitgeverij. p. 179-189.)

SWART, I. 2006. The churches and the development debate: perspectives on a fourth generation approach. Stellenbosch: Sun Press.

TAYLOR, M. 2000. Poverty and Christianity: reflections at the interface between faith and experience. London: SCM.

TOL, B. 2006. De stem uit het zuiden, willen we die wel horen? Beweging, 70(3): 2-25.

TSHIMIKA, P.K. \& LIND, T. 2003. Sharing, gifts and the global family of faith. Intercourse: Good Books.

VAN DER WALT, B.J. 1999. Kultuur, lewensvisie en ontwikkeling: ontmaskering van die gode van die onderontwikkelde Afrika en die oorontwikkelde Weste. Potchefstroom: Instituut vir Reformatoriese Studie.

VAN DER WALT, B.J. 2001. Culture, worldview and religion: towards a Biblical perspective on development. (In Van der Walt, B.J. Transformed by the renewing of your mind. Potchefstroom: The Institute for Contemporary Christianity in Africa. p. 43-92.)

VAN DER WALT, B.J. 2003. Development of the African continent. (In Van der Walt, B.J. Understanding and rebuilding Africa. Potchefstroom: The Institute for Contemporary Christianity in Africa. p. 437-457.)

VAN DER WALT, B.J. 2006a. Africa, the poorest continent: what can be done? (In Van der Walt, B.J. When African and Western cultures meet. Potchefstroom: The Institute for Contemporary Christianity in Africa. p. 1846.)

VAN DER WALT, B.J. 2006b. Development - the illusion of the twentieth century? (In Van der Walt, B.J. When African and Western cultures meet. Potchefstroom: The Institute for Contemporary Christianity in Africa. p. 4788.)

VAN DER WALT, B.J. 2006c. Leadership models in Africa, the West and the Bible. (In Van der Walt, B.J. When African and Western cultures meet. Potchefstroom: The Institute for Contemporary Christianity in Africa. p. 123-156.)

VAN TIL, K.A. 2007. Less than two dollars a day: a Christian view of world poverty and the free market. Grand Rapids: Eerdmans.

VERBEEK, G. 2005. Recht in overvloed: gerechtigheid en professionaliteit in de ontmoeting tussen arm en rijk. Budel: Uitgeverij Damon.

WIKIPEDIA. 2007. Sustainable development. http://en.wikipedia.org/wiki/ Sustainable_development Date of access: 27 Sept. 2007.

ZEYLSTRA, W.G. 1975. Aid or development: the relevance of development aid to problems of developing countries. Leiden: Sijthoff.

\section{Kernbegrippe:}

Afrika: armoede

onderontwikkeling: redes

ontwikkeling (ekonomies)

ontwikkelingsamewerking

vennootkapsverhoudings 


\section{Key concepts:}

Africa: poverty

development (economic)

development cooperation

partnership relations

underdevelopment: causes 
